\title{
Acute Intraperitoneal Mercury Chloride Contamination and Distribution in Liver, Muscle and Gill of a Neotropical Fish Hoplias malabaricus (BLOCK, 1794)
}

\author{
Taise Bomfim de Jesus ${ }^{1 *}$, Priscila Gontijo Aguiar de Almeida ${ }^{2}$, Cristiane dos Santos \\ Vergílio $^{2}$, André Luiz dos Santos Machado ${ }^{2}$ and Carlos Eduardo Veiga de Carvalho ${ }^{2}$ \\ ${ }^{I}$ Universidade Estadual de Feira de Santana, Av. Transnordestina, s/n; 44036-900; Feira de Santana - BA - Brasil. \\ ${ }^{2}$ Laboratório de Ciências Ambientais; Universidade Estadual do Norte Fluminense Darcy Ribeiro; Av. Alberto \\ Lamego, 2000; 28015-602; Campos dos Goytacazes - RJ - Brasil
}

\begin{abstract}
The present study investigated with the distribution of mercury chloride in muscle, liver and gills of Hoplias malabaricus contaminated through intraperitoneal injection (6 $\mu \mathrm{g}$ in 0.1mL of PBS) for a period of 24, 48, 72 and 96h. The liver, gill and muscle were analyzed for mercury content in an ICP/AES (Varian Liberty II) with vapor generating accessory (VGA 77). The muscle and liver tissues presented the same contamination pattern increasing concentrations in $24 \mathrm{~h}$ of exposure with a decrease in $\mathrm{Hg}$ concentration with $72 \mathrm{~h}$ and a new increase in $\mathrm{Hg}$ concentrations with 96 h of exposure. The Hg concentrations in contaminated organisms were always higher than the control although only for liver samples the difference was statistically significant. Liver samples always presented higher Hg contents when compared with gill and muscle samples.
\end{abstract}

Key words: Inorganic mercury, liver, acute effects, intraperitoneal contamination

\section{INTRODUCTION}

Though mercury $(\mathrm{Hg})$ occurs naturally in the environment, anthropogenic activities have affected its global cycle by mobilizing the increasing amounts of this metal in the environment.

Currently, such mobilization of $\mathrm{Hg}$ is larger than from natural processes (Fitzgerald and Lamborg, 2005). The different chemical forms of $\mathrm{Hg}$ have varying toxicities and organic species of $\mathrm{Hg}$. Especially methylmercury ( $\mathrm{MeHg}$ ), are more toxic because of their ability to pass the blood-brain barrier (Honda et al., 2006). Considering the environmental compartments through which $\mathrm{Hg}$ is transferred, aquatic ecosystems are very susceptible to $\mathrm{MeHg}$ contamination, as they host active populations of $\mathrm{Hg}$ methylating bacteria (Fitzgerald et al., 2007). Uptake and accumulation studies of inorganic mercury in fishes have described the relatively slow absorption and low bioavailability of these metals from water or food and the importance of both administrative routes in determining the accumulation of this metal (Olson et al., 1973; Williams and Giesy, 1978; Huckabee et al., 1979; Stary et al., 1981; Norrgren et al., 1985; Borg et al., 1988; Harrison and Klaverkamp, 1989; Glynn, 1991). The disposition of inorganic

*Author for correspondence: taisebj@ hotmail.com 
mercury in fishes has been characterized after water, oral, and intraperitoneal administration, with the pattern of tissue distribution varying depending on the administrative route. Regardless of the exposure route, the liver and kidney tended to accumulate the highest quantities of these metals (Weisbart, 1973; Sorenson, 1990). Thus, the estimates of the biological half-life after water or oral dosing may be based downward because a significant portion of the eliminated metal may not have been absorbed internally. Consequently, an improved understanding of the distribution and elimination of mercury after intravascular injection would be useful in better characterizing the persistence of these compounds in fishes.

The lack of information on the mercury kinetic within fish constrains the understanding of its distribution in these organisms and also the evaluation of potential risks for the human and animal health.

This work studied the acute exposures to $\mathrm{HgCl}_{2}$, in fish to evaluate and compare the average $\mathrm{Hg}$ concentration measured in liver, muscle and gill of Hoplias malabaricus exposed to inorganic mercury. The necessary increase the biological knowledge about this tropical species and the pharmacokinetic of the metal contamination for further use in field assessment.

\section{MATERIALS E METHODS}

Hoplias malabaricus specimens were collected, between July and October 2006 from the lakes located at Itaocara municipality, northwest of Rio de Janeiro State (21 $40^{\prime} 44^{\prime}$ 'S e $42^{\circ} 04^{\prime} 53^{\prime \prime}$ W). The lakes are located in a forested area with little influence of anthropogenic and point sources of pollutants. No agricultural activities were placed in the surroundings or in the lake catchment.

After the sampling, the specimens were transported to the lab in plastic bags. In the lab, the wounded and sick specimens (about 3\% of the sampling specimens) were discarded in order to use only healthy specimens in the experiment. The organisms were then placed in aquarium with continuous water flux for seven days for acclimitization. Table 1 presents the number, average weight and standard length (with the standard deviation) of the specimens used in the experiment for each of the exposure times.

Table 1 - Number of muscle (M), gill (G) and liver (L) samples analyzed in each time exposure experiments with the average weight, standard length (with standard deviation) and concentration tested in relation with weigth of the used Hoplias malabaricus specimens.

\begin{tabular}{cccccc}
\hline Time $(\mathrm{h})$ & M & L & G & Weight $(\mathrm{g})$ & Tested Concentration $(\mu \mathrm{g} . \mathrm{g})$ \\
\hline 24 & 8 & 8 & 8 & $99 \pm 34$ & 0,0606 \\
48 & 8 & 6 & 8 & $93 \pm 17$ & 0,0645 \\
72 & 8 & 6 & 7 & $87 \pm 23$ & 0,0689 \\
96 & 8 & 4 & 4 & $116 \pm 11$ & 0,0517 \\
\hline
\end{tabular}

The mercury chloride solution was prepared diluting $0.015 \mathrm{~g}$ of $\mathrm{HgCl}_{2}$ in $0.5 \mathrm{~mL}$ of $4 \mathrm{~N} \mathrm{HCl}$ and made to $250 \mathrm{~mL}$ with PBS (Phosphate Buffer Solution). This solution was used in the acute intraperitoneal contamination experiment. The volume of mercury chloride solution that was injected into the peritoneal cavity of the studied fish was $0.1 \mathrm{~mL}$ with $6 \mu \mathrm{g}$ of $\mathrm{Hg} / \mathrm{fish}$. The concentration tested in relation to the weight of each individual is described in Table 1. The mean concentration tested in each fish was $0.0614 \mu \mathrm{g}$.g. After the injection of the $\mathrm{Hg}$ solution, the fish was placed in the aquarium and in the intervals of 24 , 48, 72 and $96 \mathrm{~h}$ the specimens were measured, weighed and opened in order to remove the liver, muscular and gill tissue samples. The control samples were also collected from the fishes that were injected with $0.1 \mathrm{~mL}$ PBS only.

Aliquots of approximately $1 \mathrm{~g}(\mathrm{w} / \mathrm{w})$ of liver, gills and muscle samples were submitted to strong acid digestion in triplicate following a modified methodology described by Bastos et al. (1998). All $\mathrm{Hg}$ determinations were done in a Varian ICPAES (model Liberty II) with cold vapor generating accessory (VGA 77). In order to verify the possible contamination of the extracts, chemical blanks were prepared and analyzed for each group of 10 samples.

The precision of the methodology was tested through the analysis of certified reference material 
- DORM 1 - supplied by the "Marine Analytical Chemical Standards Programs", Canada. The recovery of the certified value was $98.92 \%$. In order to verify the differences among the $\mathrm{Hg}$ concentrations within the distinct tissues at all exposure times, an ANOVA (Main effects), with significance level of $95 \%(\mathrm{p}<0.05)$ was used. A Student $\mathrm{T}$ Test was also used to compare the $\mathrm{Hg}$ concentrations among the contaminated studied tissues. The statistical software used was Statistic for Windows version 6 .

\section{RESULTS AND DISCUSSION}

Laboratory studies on the analysis of stress responses in the tissues of organisms exposed to metal can help to understand the mechanism through which metals exert their toxicity on the organisms. These results could be used to explain the impact of heavy metal toxicity on the organisms in the field. Mercuric chloride has been studied extensively as a model of nephrotoxicity for several animal species. However, little information is available on the toxic effect of $\mathrm{HgCl}_{2}$ (Boujbiha et al., 2009).

The average $\mathrm{Hg}$ concentration measured in the liver was always higher $\left(744 \mu \mathrm{g} \cdot \mathrm{kg}^{-1}\right)$ than the concentrations measured in the gills $\left(339 \mu \mathrm{g} \cdot \mathrm{kg}^{-1}\right)$ and muscle $\left(68 \mu \mathrm{g} \cdot \mathrm{kg}^{-1}\right)$, and a significant difference $\left(\mathrm{p}=2.2 \times 10^{-5}\right)$ was observed among the studied tissues (Table 2).

The $\mathrm{Hg}$ concentration in muscle of the organisms, initially increased in the first $48 \mathrm{~h}$ of contamination $\left(58 \mu \mathrm{g} \cdot \mathrm{kg}^{-1}\right.$ and $\left.90 \mu \mathrm{g} \cdot \mathrm{kg}^{-1}\right)$. After 72 $\mathrm{h}$, a decrease in $\mathrm{Hg}$ concentrations was observed $\left(53.3 \mu \mathrm{g} . \mathrm{kg}^{-1}\right)$ and at $96 \mathrm{~h}$ another increase in $\mathrm{Hg}$ concentration was observed $\left(68.8 \mu \mathrm{g} \cdot \mathrm{kg}^{-1}\right)$ (Fig. 1).

Table 2 - Average mercury concentrations $\left(\mu \mathrm{g} \cdot \mathrm{kg}^{-1}\right)$ in muscle, gill and liver of Hoplias malabaricus in all studied exposure times.

\begin{tabular}{cccc}
\hline E.T.* & Liver & Gill & Muscle \\
\hline Control & $127 \pm 24$ & $54 \pm 13$ & $57 \pm 5$ \\
24 & $370 \pm 156$ & $276 \pm 108$ & $58 \pm 6.4$ \\
48 & $714 \pm 248$ & $267 \pm 27$ & $90 \pm 13.9$ \\
72 & $633 \pm 235$ & $284 \pm 78$ & $57 \pm 13.4$ \\
96 & $1260 \pm 753$ & $529 \pm 273$ & $68 \pm 12.0$ \\
\hline
\end{tabular}

*Exposure time in hours.

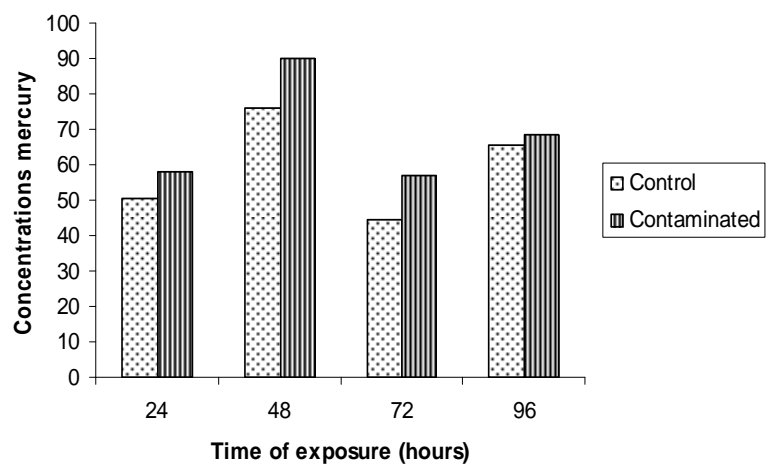

Figure 1 - Average mercury concentrations ( $\mu \mathrm{g} \cdot \mathrm{kg}^{-1}$ ) in fish muscle (Hoplias malabaricus) at different times of exposure (hours).

The total mercury values measured in the muscles of the control specimens collected from the lagoons of Itaocara-RJ were considered low when compared to the total mercury values found for the fish of the same species collected from the Paraíba do Sul River (averages from 137 to $235 \mu \mathrm{g} \cdot \mathrm{kg}^{-1}$ ), which was the source of fish for this region (Yallouz et al., 2000). Yet, comparing the mercury 
values measured in the muscles of "traíra" injected with $\mathrm{HgCl}_{2}$ to the WHO values, the findings were below the established limit (500ng.g).

No significant difference was observed $(\mathrm{p}=0.56)$ when $\mathrm{Hg}$ concentrations from the contaminated and control muscle samples were compared. This could be explained by the short time of exposure of individuals to mercury, since the $\mathrm{Hg}$ is transported by the blood to the liver and other tissues to then be stored in the muscle.

The Hg concentration results in the gills (Fig. 2) showed a more homogeneous pattern of $\mathrm{Hg}$ in the control samples (average $54.4 \pm 13.7 \mu \mathrm{g} \cdot \mathrm{kg}^{-1}$ ) as well as in the first three periods of exposure (24, 48 and $72 \mathrm{~h}$ ) (average $276 \pm 8.4 \mu \mathrm{g} \cdot \mathrm{kg}^{-1}$ ). After 96 $\mathrm{h}$, the gills showed $\mathrm{Hg}$ concentrations three times higher than the previous time of exposure and 10 times higher when compared to average concentrations of the control. When comparing the gill $\mathrm{Hg}$ concentrations of the contaminated specimens among the distinct exposure times, a significant difference ( $\mathrm{p}=0.004293$ ) was observed. A significant difference was also observed when $\mathrm{Hg}$ concentrations in the control and contaminated samples were compared $\left(\mathrm{p}=5.79 \times 10^{-7}\right)$.

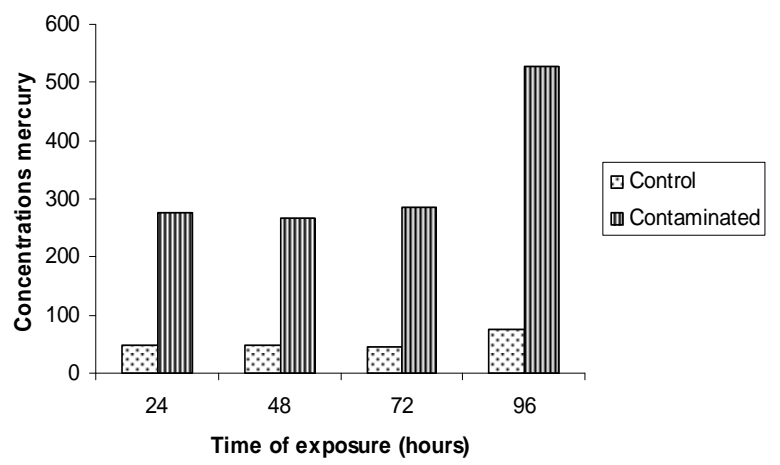

Figure 2 - Average mercury concentrations $\left(\mu \mathrm{g} \cdot \mathrm{kg}^{-1}\right)$ in fish gill (Hoplias malabaricus) at different times of exposure (hours).

The high mercury concentrations observed in the gill of the fishes under a regime of $96 \mathrm{~h}$ exposure were probably a consequence of its after metabolization release to the water and reabsorption by the gills.

Mercury distribution in the liver of contaminated specimens followed the same pattern described for the gill, although the observed concentrations were higher. Therefore, an increase of $\mathrm{Hg}$ concentrations within $48 \mathrm{~h}$ after the contamination was observed $\left(370 \mu \mathrm{g} \cdot \mathrm{kg}^{-1}\right.$ in $24 \mathrm{~h} ; 714 \mu \mathrm{g} \cdot \mathrm{kg}^{-1}$ in $48 \mathrm{~h})$ with a decrease in concentrations after 72 hours of exposure $\left(633 \mu \mathrm{g} \cdot \mathrm{kg}^{-1}\right)$ and a second increase in $\mathrm{Hg}$ concentrations after $96 \mathrm{~h}$ of

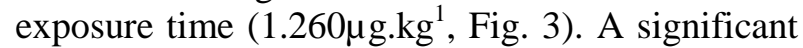
difference was observed between the liver contaminated samples and liver control samples $\left(\mathrm{p}=2.7 \times 10^{-5}\right)$.

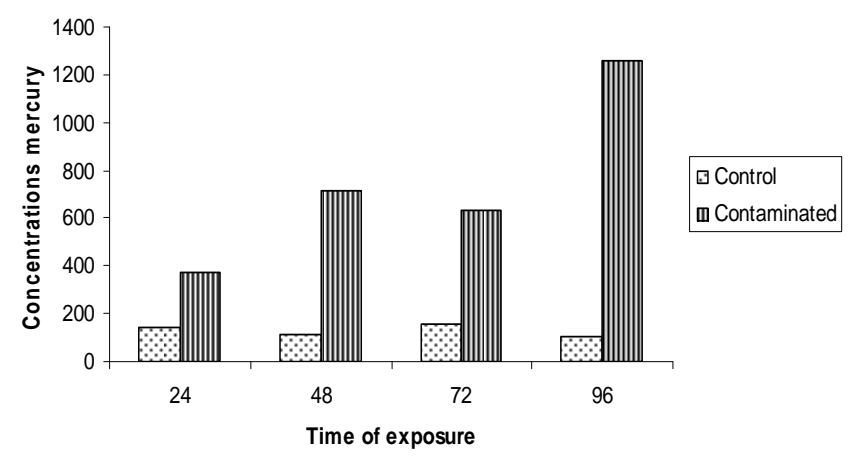

Figure 3 - Average mercury concentrations ( $\mu \mathrm{g} \cdot \mathrm{kg}^{-1}$ ) in fish liver (Hoplias malabaricus) at different exposure times (hours). 
The average observed $\mathrm{Hg}$ concentration in the liver and muscle of the fishes differed significantly $\left(\mathrm{p}=2.2 \times 10^{-5}\right)$. The average values were $744 \mu \mathrm{g} . \mathrm{kg}^{-1}$ and $68 \mu \mathrm{g} \cdot \mathrm{kg}^{-1}$, respectively (Table 2).

The average $\mathrm{Hg}$ concentrations obtained from the contaminated organs followed the sequence: Liver $>$ Gill > Muscle. According to Frodello et al. (2000) and Gonzalez et al. (2005), the demethylation from the organic to the inorganic $\mathrm{Hg}$ occurs in the hepatocytes. Besides that, the bile released by the liver during the digestion might cause the dispersion of the $\mathrm{Hg}$ to other tissues (Allen et al., 1988). Similar results were mentioned by Simon and Boudou (2001) in Ctenopharyngodon idella contaminated with $\mathrm{HgCl}_{2}$ and $\mathrm{MeHg}$ and by Kenedy (2003) in Carassius auratus exposed to inorganic $\mathrm{Hg}$ originated from the dental amalgam. OliveiraRibeiro et al. (1996) and Schultz et al. (1996) also observed the same tendency in Trichomycterus zonatus exposed to $\mathrm{HgCl}_{2}$ in water and Ictalarus punctatus injected with $\mathrm{HgCl}_{2}$ respectively. Similar results were obtained by Liao et al. (2005) with higher $\mathrm{Hg}$ concentrations observed in liver followed by kidney and muscle. In both the studies (present and Liao et al., 2005), the $\mathrm{Hg}$ concentrations observed in all the tissues were a consequence of the exposure time and the injected concentration. In natural environment, high concentrations of $\mathrm{Hg}$ in the liver and kidneys of aquatic animals were observed by Frodello et al. (2000) in the species of Cetacea, by Régine et al. (2006)in Acnodon oligacanthus, Pseudodancistrus barbatus, Semaprochilodus varii, Doras micropoeus, Hoplias aimara and Cynodon gibbus, by Afonso et al. (2007) in Aphanopus carbo and by Raldúa et al. (2007) in Barbus graellsii and Alburnus alburnus.

Schultz and Newman (1997) observed the same trend as the present study after the first administration of inorganic $\mathrm{Hg}$ to a channel catfish. Most of the $\mathrm{Hg}$ eventually became concentrated in the liver with only trace quantities accumulating in skeletal muscle. However, some species presented the inverse, as Cyprinus carpio (Goldstein et al., 1996), Leporinus friderici and Leporinus fasciatus (Régine et al., 2006), which showed higher $\mathrm{Hg}$ accumulation in the skeletal muscle instead of the previously mentioned organs. Gonzalez et al. (2005) studied the bioaccumulation of $\mathrm{Hg}$ in Danio rerio fed with a diet containing $\mathrm{MeHg}$ (5.0 and $13.5 \mathrm{mgHg} \cdot \mathrm{g}^{-1}$ ).
According to Régine et al. (2006), who compared the $\mathrm{Hg}$ distribution in different fishes, there was a great difference based on the feeding habit of each species, besides that, the structural and functional characteristics of each species could modify the organotropism of $\mathrm{Hg}$. Cano (2001) highlighted that the chemical form of $\mathrm{Hg}$ (organic or inorganic), concentration, the contamination path (exposure or ingestion), and depuration/excretion mechanism could interfere the Hg kinetics within organisms.

The muscle tissue has been indicated for the assessment of mercury contamination levels in the fishes from impacted environments, because of the preference of the organic form for that tissue (Akagi, 1995; Richardson et al., 1995). However, as it could be observed on the concentrations obtained from the different tissues here analyzed, the muscle tissue was not the best tissue to assess the level of contamination by inorganic mercury. Carvalho et al., (2009) analyzing the mercury levels in the muscles of "Tilapia" observed that the concentrations of mercury in this tissue could be insignificant in comparison to other organs. This observation was relevant, since the fish tissue consumed by humans was the muscle tissue and "Tilapia" showed resistance to the absorption of mercury in the muscle, even when exposed to high concentrations of that element, a conclusion similar to the one reached in the present study.

The distribution of mercury in the fish tissues results in the actions and interactions between the factors such as the exposure condition (importance of the entrance path via water/diet or intraperitoneal injection) and the chemical forms of the metal (inorganic mercury $\mathrm{Hg}(\mathrm{II}) / \mathrm{MMHg}$ ) (Boudou and Ribeyre, 1997; Jackson, 1998; Wiener et al., 2003; Régine et al., 2006). Thus, the intraperitoneal administration path of the $\mathrm{HgCl}_{2}$ contributed to the high total concentrations of $\mathrm{Hg}$ observed in the liver and gill of the fish. After the intraperitoneal injection, the chemical quickly enters the bloodstream through the portal vein, which drains the blood directly to the liver, where the mercury and nutrients are absorbed by the digestive system, metabolized and distributed through the systemic bloodstream, which carries the non-oxygenated blood that passes through the heart and is pumped to the gills, where it is oxygenated. Only then the blood is distributed to the body.

On the other hand the muscular tissue did not present affinity with inorganic mercury forms, 
although this tissue was the main storage site of the organic mercury forms (Oliveira-Ribeiro et al., 1996; Olson et al., 1978; WHO, 1990).

Apparently, mercury distribution took approximately $24 \mathrm{~h}$ in most organs, except the head, where the peaks of radioactivity in an experimental situation were only achieved in two or three days (HSDB, 2000). This feature was important to determine the first time of exposure of fish to the metal in the experiment in question. Variations in the concentrations of $\mathrm{Hg}$ in the liver and muscle are common when animals are subjected to a single dose of the contaminant. Schultz et al., (1996) had observed a decrease in $\mathrm{Hg}$ concentrations in the muscle after $24 \mathrm{~h}$ of exposure in a study developed with inorganic $\mathrm{Hg}$ intravascular administration in Ictalurus punctatus (Rafinesque, 1818) for 12, 24, 48 and $72 \mathrm{~h}$. This behavior would normally be interpreted as the result of excretion of the metals from the animal. Although Oliveira et al., (1996), studying the effect of the exposure of Trichomycterus zonatus of inorganic mercury in the water in successive daily doses, observed a continuous growth of the concentration of metal with the time of exposure, with no decrease in any of the exposure times.

Part of $\mathrm{Hg}$ eliminated by the bile in the intestine suffers enterohepatic cycle and is probably reabsorbed into the blood. This process is surely responsible for the decrease in the mercury elimination rate and in the increase in its accumulation, and it also could explain the second rise in concentrations observed in the $96 \mathrm{~h}$ exposure (WHO, 1990). The mercury accumulation pattern in different tissues of $H$. malabaricus indicates a degree of organ specificity, which may be related to the differences in physiological functions (Krishnakumar et al. 1990; James et al. 1993).

This result is similar to other work that report the toxicity of mercury in tropical or subtropical carnivores fishes, submitted to acute tests in laboratory. The highest mercury concentrations found in the liver, when compared to muscle and gills, could affect the histology and consequently the functionality of the body. Therefore, this would cause inefficiency in the metabolism and excretion of these toxic substances.

\section{REFERENCES}

Afonso, C., Lourenço, H.M., Dias, A., Nunes, M.L., Castro, M. (2007), Contaminant metals in black scabbard fish (Aphanopus carbo) caught off Madeira and the Azores. Food Chem., 101, 120-125.

Akagi, H., Malm, O., Braches, F.J.P. (1995), Human exposure to mercury due to mining in the Amazon, Brazil-a review. Environmental science, 3, 199-211.

Allen, P., Yoke, S.. Keong, W.M. (1988), Acute effects of mercury chloride on intracellular CSH level and mercury distribution in the fish Oreochromis aureus. Bull. Environ. Contam. Toxicol. 40, 178-184.

Bastos, W.R., Malm, O., Pfeiffer, W.C., Cleary, D. (1998), Establishment and analytical quality control of laboratories for $\mathrm{Hg}$ determination in biological and geological samples in the Amazon, Brazil. Cienc. Cult., 50, 255-260

Borg, K., Gottofrey, J., and Tjalve, T. (1988). Effects of some chelating agents on the uptake and tissue distribution of $203 \mathrm{Hg}^{2+}$ in the brown trout (Salmo trutta): Studies on ethyl- and isopropylxanthate, diethyl- diisopropyldithiophosphate, dimethyl- and diethyldithiocarbamate and pyrinethione. Arch. Toxicol. 62, 387-391.

Boudou, A. and Ribeyre, F. (1997), Aquatic ecotoxicology: From the ecosystem to the cellular and molecular level. Environmental Health Perspectives, 105, 21-35.

Boujbiha, M.A, Hamden, K., Guermazi, F., Bouslana, A., Omezzine, A., Kammoun, A. and El Feki, A. (2009), Testicular toxicity in mercury chloride treated rats: Association with oxidative stress. Reproductive Toxicology, 28, 81-89.

Cano, E.S. (2001), Toxicología del mercurio. Actuaciones preventivas em Sanidad laboral y ambiental. In: Jornada Internaticonal sobre el impacto ambiental del mecurio utilizado por la mineria aurífera artesanal em Iberoamérica, Lima. Anais eletrônicos... Lima, Disponível em: http://www.gama-peru.org/jornadahg/espanol.pdf.

Acesso em: 14 nov. 2006.

Carvalho, G.G.A., França, J.G., Dias, D.C., Lombardi, J.V., Paiva, M.J.R., Carvalho, S., Sarriés, G.A., Ferreira, J.R. (2009), Bulletin of Environmental Contamination and Toxicology, 82, 300-304.

Fitzgerald, W.F., Lamborg, C.H., (2005), Geochemistry of mercury in the environment. In: H.D. Holland and K.K. Turekian, Editors, Treatise on Geochemistry, Environmental Geochemistry, 9, Elsevier, San Diego, USA, pp. 108-148. 
Fitzgerald, W.F., Lamborg, C.H., Hammerschmidt, C.R. (2007), Marine biogeochemical cycling of mercury, Chem. Rev. 107, 641-662.

Frodello, J.P., Roméo, M., Viale, D. (2000), Distribution of mercury in the organs and tissues of five toothed-whale species of the Mediterranean. Environmental Pollution, 108, 447-452.

Glynn, A. W. (1991). Cadmium and zinc kinetics in fish: Studies on water- borne $109 \mathrm{Cd}$ and $65 \mathrm{Zn}$ turnover and intracellular distribution in minnows Phoxinus phoxinus. Pharmacol. Toxicol. 69, 485491.

Gochefeld, M. (2003), Cases of mercury exposure, bioavailability, and absorption. Ecotoxicol. Environ. Saf. 56,174-179

Goldstein, R.M., Brigham, M.E., Stauffer, J.C. (1996), Comparison of mercury concentrations in liver, muscle, whole bodies, and composites of fish from the Red river of the North. Can. J. Fish. Aquat. Sci. 53, 244-252.

Gonzalez, P., Dominique, Y., Massabuau, J.C., Boudou, A., Bourdineaud, J.P. (2005), Comparative effects of dietary methylmercury on gene expression in liver, skeletal muscle, and brain of the zebrafish (Danio rerio). Environ.Sci. Technol, 39, 3972-3980.

Harrison, S. E., and Klaverkamp, J. F. (1989). Uptake, elimination and tissue distribution of dietary and aqueous cadmium by rainbow trout (Salmo gairdneri Richardson) and lake whitefish (Corregonus clupeaformis Mitchill). Environ. Toxicol. Chem. 8, 87-97.

Honda, S., Hylander, L., Sakamoto, M., (2006), Recent advances in evaluation of health effects on mercury with special reference to methylmercury-a minireview, Environ. Health Prev. Med. 11, 171-176.

HSDB - Hazardous Substances Data Bank. (2000), Mercury. In: Tomes Cps Siystem. Toxicology, occupational medicine and environmental series. Englewwod: Micromedex. CD-ROM

Huckabee, J.W., Elwood, J.W., Hildebrand. S.G. (1979), Accumulation of mercury in freshwater biota. In J.O. Nriagu, ed., The Biogeochemistry of Mercury in the Environment. Elsevier/ North-Holland, New York, NY, USA, pp. 277-302.

Kennedy, C. J. (2003), Uptake and accumulation of mercury from dental amalgam in the common goldfish, Carassius auratus. Environmental Pollution, 121, 321-326.

Krishnakumar, P.K., Damodaran, R. and Nambisan, P.N.K. 1990. Accumulation, distribution and depuration of mercury in the green mussel Perna viridis (Linnaeus). Proc. Indian Acad. Sci. 99, 345352.
Jackson TA. (1998). Mercury in aquatic ecosystems. In: Langston WJ, Bebianno MJ, editors. Metal metabolism in aquatic environments. London, Chapman and Hall;. p. 97-159.

James, R., Sampath, K., Devakiamma, G. 1993. Accumulation and Depuration of mercury in a Catfish Heterooneustes fossilis (Pisces: Heteropneustidae) exposed to sublethal doses of the element. Asian Fisheries Science, 6, 183-191.

Liao, C.Y., Zhou, Q.F., Shi, J.J.B. and Fu, G.B., Jiang (2005), Mercury Accumulation and Distribution in Medaka after the Exposure to Sublethal Levels of Methylmercury. Bull. Environ. Contam. Toxicol., 75, 584-591

Mela, M. (2004), Uso de biomarcadores na avaliação dos efeitos do metilmercúrio em Hoplias malabaricus (BLOCK, 1794) (Traíra). 2004. 124f. Dissertação (Mestrado em Biologia cellular e molecular) Departamento de Biologia Celular, Setor de Ciências Biológica, Universidade Federal do Paraná, Curitiba.

Norrgren-Karlsson, L., and Runn, P. (1985). Cadmium dynamics in fish: Pulse studies with $109 \mathrm{Cd}$ in female zebrafish, Brachydanio rerio. J. Fish. Biol. 27, 571581.

Oliveira Ribeiro, C.A., Guimarães, J.R., Pfeiffer, W.C. (1996), Accumulation and distribution of inorganic mercury in a tropical fish (Trichomycterus zonatus). Ecotoxicol. Environ. Saf., 34, 190-195

Olson, K.R., Bergman, H.L., Fromm, P.O. (1973), Uptake of methyl mercuric chloride and mercuric chloride by trout: A study of uptake pathways into the whole animal and uptake by erythrocytes in vitro. $J$. Fish. Res. Board. Can. 30,1293-1299.

Olson, K.K., Squibb, K.S., Cousins, R.J. (1978), Tissue uptake, subcellular distribution, and metabolism of $\mathrm{CH}_{3} \mathrm{HgCl}$ by rainbow trout, Salmo gairdneri. J. Fish. Research Board Can., 35, 381-390

Raldúa, D., Díez, S., Bayona, J.M., Barceló, D. (2007), Mercury levels and liver pathology in feral fish living in the vicinity of a mercury cell chlor-alkali factory. Chemosphere. 66, 1217-1225.

Régine, M.B., Gilles, D., Yannick, D., Boudou, A. (2006), Mercury distribution in fish organs and food regimes: Significant relationships from twelve species collected in French Guiana (Amazonian basin). Sci. Total. Environ., 368, 262- 270

Richardson, G.M., Egyed, M., Currue, D.J. (1995), Does acid rain increase human exposure to mercury? A Review and analysis of recent literature. Environmental toxicology and chemistry, 14, 809 813. 
Schultz, R.I., Newman, C.M. (1997), Methylmercury Toxicokinetics in channel catfish (Ictalurus punctatus) and largemouth bass (Micropterus Salmoides) after intravascular administration. Environ. Toxicol. and Chem. 16 (5), 990-996.

Schultz, R.I., Peters, L.E., Newman, C.M. (1996), Toxicokinetics and disposition of inorganic mercury and cadmium in channel catfish after intravascular administration. Toxicol. and Apllied Pharm., 140, 3950

Simon, O., Boudou, A. (2001), Direct and trophic contamination of the hervivorous carp ctenopharyngodon idella by inorganic mercury and methylmercury. Ecotoxicology and Environmental Safety, v. 50, 48-59.

Sorensen, E. (1991), Mercury. CRC Press, Boca Raton, FL

Stary, J., Havlik, B., Kratzer, K., Prasilova, J., and Hanusova, J. (1981). Mercury circulation in aquatic environment. Part 4: The accumulation inorganic mercury and phenylmercury by Fish (Poecilia reticulata (Peters)). Acta Hydrochim. Hydrobiol. 9, 545-553.
Wiener JG, Krabbenhoft DP, Heinz GH, Scheuhammer AM. (2003).Ecotoxicology of mercury. In: Hoffman DJ, Rattner BA, Burton GA, Cairns J, editors. Handbook of ecotoxicology. Boca Raton, Lewis Publ; p. 409- 63 .

WHO. (1990), World Health Organization. Environmental Health Criteria 101. Methylmercury. Geneve, Switzerland: World Health Organization.

Wiliams, D.R., Giesy, JR (1978), Relative importance of food and water sources to cadmium uptake by Gambusia affinis (Poeeiliidae). Environ. Res. 16, 326-332

Yallouz, A.V., De Campos, R.C., Paciornik, S. (2000), A low-cost non-instrumental method for semiquantitative determination of mercury in fish. Fres. J. Anal. Chem. 366, 461-465.

Received: December 01, 2008; Revised: August 12, 2009; Accepted: November 11, 2010. 